Огляди літератури, оригінальні дослідження, погляд на проблему, ювілеї

УДК 616.12-008.331.1-06:616.13-007.272-085.225.2

DOI 10.11603/1811-2471.2018.v0.i4.9734

\title{
РАЦІОНАЛЬНИЙ ВИБІР КОМБІНАЦІЇ АНТИГІПЕРТЕНЗИВНИХ ПРЕПАРТІВ ПРИ АРТЕРІАЛЬНІЙ ГІПЕРТЕНЗІЇ З ОБЛІТЕРУЮЧИМ АТЕРОСКЛЕРОЗОМ НИЖНІХ КІНЦІВОК В АМБУЛАТОРНІЙ ПРАКТИЦІ
}

\author{
๑Л. С. Бабінець, В. В. Білочицька, Ю. Я. Коцаба \\ ДВНЗ «Тернопільський державний медичний університет імені І. Я. Горбачевського МОЗ України»
}

\begin{abstract}
РЕзЮМЕ. Проведено дослідження впливу комбінації антигіпертензивних препаратів на основні показники центральної та периферійної гемодинаміки 96 хворих на артеріальну гіпертензію з атеросклеротичним ураженням периферійних артерій нижніх кінцівок.

Мета дослідження - вивчити вплив антигіпертензивних препаратів різних груп першої лінії на центральну, периферійну та внутрішньосерцеву гемодинаміку з метою вибору оптимальної комбінації цих препаратів для лікування хворих на артеріальну гіпертензію із ураженням периферійних артерій нижніх кінцівок на етапі первинної медичної допомоги.

Висновки. Порівняння впливу комбінацій карведилол+гідрохлортіазид, телмісартан+гідрохлортіазид і лізиноприл+амлодипін показало таке: 1) зазначені комбінації антигіпертензивних препаратів забезпечують стабільний і рівномірний гіпотензивний ефект протягом доби і мають коригуючий вплив на добовий профіль артеріального тиску, достовірно знижуючи середньодобовий, середньоденний і середньонічний систолічний і діастолічний артеріальний тиск, а також частоту серцевих скорочень; 2) зазначені комбінації антигіпертензивних препаратів у хворих на АГ, що поєднується із атеросклеротичними ураженнями магістральних артерій нижніх кінцівок, при гіперкінетичному або еукінетичному типі центральної гемодинаміки із превалюванням симпатичної нервової системи позитивно впливають на основні показники центральної та периферійної гемодинаміки; 3) комбінацію антигіпертензивних препаратів лізиноприл+амлодипін слід вважати найбільш вдалою для лікування хворих на артеріальну гіпертензію у поєднанні з атеросклеротичними ураженнями магістральних артерій нижніх кінцівок за впливом на досягнення цільового рівня артеріального тиску протягом 6 місяців, за сумарним впливом на параметри загального і питомого периферійного судинного опору і рівень ремоделювання судин (за товщиною комплексу інтима-медіа); 4) позитивний вплив досліджених комбінацій антигіпертензивних препаратів на периферійну гемодинаміку дозволяє зменшити дозу судинорозширювальних препаратів, що застосовуються для лікування хронічної артеріальної ішемії нижніх кінцівок.
\end{abstract}

КлючовІ СлОВА: артеріальна гіпертензія; антигіпертензивна терапія; облітеруючий атеросклероз; карведилол; телмісартан; амлодипін.

Вступ. Артеріальна гіпертензія (АГ) - одне з найпоширеніших неінфекційних хронічних захворювань людини, котре трапляється у $40 \%$ населення України і призводить до інвалідизації та високого рівня смертності. Особливо небезпечною АГ стає при їі поєднанні з оклюзійними захворюваннями артерій нижніх кінцівок [1]. У наш час не викликає сумнівів той факт, що підвищений рівень артеріально го тиску (АТ) - це патологічний стан, який спричиняє такі серйозні ускладнення як гіпертензивний криз, порушення мозкового кровообігу, застійну серцеву недостатність або ниркову недостатність, ураження аорти, периферійних артерій і судин сітківки. Головним стратегічним завданням антигіпертензивної терапії $\epsilon$ зниження числа таких ускладнень АГ як інсульт, інфаркт міокарда, серцева недостатність, виникнення та прогресування ішемії нижніх кінцівок. Запобігти ускладненням можна лише за умов досягнення i утримання контролю над АТ на рівні цільового, проведення адекватного лікування пацієнтів з АГ, що включає в себе, з одного боку, зниження АТ до цільових рівнів, а з іншого - зворотний розвиток патологічних змін в уражених органах - серці, нирках, артеріальних судинах [3].

Залишається невирішеним і недостатньо висвітленим питання лікування АГ на тлі атеросклеротичних уражень магістральних артерій нижніх кінцівок. Адже особливості стану центральної та периферійної гемодинаміки у цієї категорії хворих вимагають індивідуального підходу до вибору гіпотензивних препаратів та їх комбінацій [2]. Більше того, виконання реконструктивних оперативних втручань при оклюзії магістральних артерій, особливо на артеріях великого діаметра, здатне змінювати параметри центральної та периферійної гемодинаміки. Недооцінка цього факту при призначенні антигіпертензивних препаратів може стати причиною ускладнень з боку серцево-судинної системи та прогресування ішемії кінцівки $[1,5]$. Тому вважали актуальним дослідити вплив антигіпертензивних препаратів різних груп першої лінії на центральну, периферійну та внутрішньосерцеву гемодинаміку з метою вибору оптимальної комбінації цих препаратів для лікування хворих на АГ із ураженням периферійних артерій нижніх кін- 
Огляди літератури, оригінальні дослідження, погляд на проблему, ювілеї

цівок для прогнозовано ефективного і максимально безпечного ведення таких пацієнтів в умовах первинної медичної допомоги [4].

Мета дослідження - вивчити вплив антигіпертензивних препаратів різних груп першої лінії на центральну, периферійну та внутрішньосерцеву гемодинаміку з метою вибору їх оптимальної комбінації для лікування хворих на артеріальну гіпертензію із ураженням периферійних артерій нижніх кінцівок на етапі первинної медичної допомоги.

Матеріал і методи дослідження. До дослідження були включені хворі (n=96) із АГ 1-3 ступеня, у яких клінічними та інструментальними методами дослідження було виявлено атеросклеротичні ураження артерій нижніх кінцівок (оклюзії в стегно-підколінному сегменті), II A-III А стадії хронічної артеріальної недостатності. Згідно з критеріями ВОО3 та Рекомендаціями робочої групи ESH/ESC (2017) групу дослідження становили хворі на АГ з рівнем систолічного АТ (САТ) 140 мм рт. ст. і вище і/або діастолічного АТ (ДАТ) 90 мм рт. ст. і більше або з нормальним рівнем АТ при антигіпертензивному лікуванні протягом останніх двох тижнів. Серед хворих на АГ було 82 (85,41 \%) чоловіки і 14 (14,58 \%) жінок віком від 30 до 70 років. Переважна більшість хворих (86,00-89,58 \%) була працездатного віку: 21 пацієнт (21,88 \%) віком 3040 років; 37,06 \% - віком 41-50 років. Серед цих хворих вперше виявлена АГ була у 18 (18,75 \%) пацієнтів; у 78 (81,25 \%) хворих тривалість АГ склала в середньому $(8,6 \pm 1,1)$ років. 1 ступінь АГ виявлено у 24 (25,0 \%) пацієнтів, 2 ступінь - у 61 хворого (63,54 \%), 3 ступінь - у 11 (11,45 \%) хворих. Критеріями виключення із дослідження були наступні: симптоматичний характер АГ, ізольована гіпертензія, інфаркт міокарда, перенесений за 3 місяці до дослідження, нестабільна стенокардія або стенокардія напруги III-IV функціонального класу, гемодинамічно значущі порушення ритму та провідності серця, серцева недостатність III-IV класу за NYHA, інсульт, ниркова і печінкова недостатність, хронічні захворювання органів дихання і травного тракту у фазі загострення, злоякісні, автоімунні та ендокринні захворювання (крім інсулінонезалежного цукрового діабету в стадії компенсації), вираженого ожиріння (індекс маси тіла понад 49 кг/м²), хворі із хронічною артеріальною недостатністю нижніх кінцівок III Б-IVст. (трофічна виразка та гангрена кінцівки), алкогольна залежність. Таким чином, із дослідження були виключені хворі із станами, які могли певним чином впливати на оцінку параметрів, які вивчались, насамперед на центральну і периферійну гемодинаміку.

3 метою найраціональнішого вибору антигіпертензивної терапії була проведена порівняль- на оцінка впливу на основні показники системної та внутрішньосерцевої гемодинаміки наступних комбінацій препаратів: карведилолу 12,5 мг із гідрохлортіазидом 12,5 мг, телмісартану 80 мг із гідрохлортіазидом 12,5 мг, лізиноприлу 10 мг із амлодипіном 5 мг.

Результати й обговорення. Були встановлені наступні особливості центральної та периферійної гемодинаміки при АГ: а) у 25,12 \% хворих - гіперкінетичний, у 29,18 \% - еукінетичний, у 36,86 \% - гіпокінетичний типи центральної гемодинаміки; б) у 86,36 \% хворих із гіперкінетичним і еукінетичним типом центральної гемодинаміки переважав симпатичний компонент вегетативної нервової системи (BНC) із розвинутою колатеральною сіткою та максимальною кількістю функціонуючих колатеральних гілок, а у 56,00 \% хворих із гіпокінетичним і еукінетичним типами центральної гемодинаміки переважав парасимпатичний компонент ВНС.

Аналіз зниження АТ за даними добового моніторингу засвідчив найбільший ефект через місяць прийому хворими комбінації лізиноприлу і амлодипіну: відмічено зниження САТ середньодобового, САТ середньоденного та САТ середньонічного відповідно на $(19,6 \pm 1,1)$ мм рт. ст, $(15,3 \pm$ $1,6)$ мм рт. ст. і $(21,2 \pm 1,5)$ мм рт. ст. у порівнянні із початковими даними. Зниження АТ у групах пацієнтів, що застосовували комбінації карведилолу з гідрохлортіазидом і телмісартану з гідрохлортіазидом, було зіставним за рівнем зниження АТ, однак виявилося достовірно нижчим, ніж у групі із застосуванням лізиноприлу з амлодипіном $(p<0,05)$. Через 6 місяців від початку лікування спостерігалося значне зниження АТ у пацієнтів усіх трьох груп (у середньому на 10,51 \%, 7,93 \% і 12,62%), але найбільший гіпотензивний ефект виявлено при застосуванні комбінації лізиноприлу з амлодипіном ( $<0,05)$. Комбінація телмісартану з гіпотіазидом (Мікардис Плюс), порівняно з комбінацією карведилолу з гідрохлортіазидом, мала нижчий антигіпертензивний ефект $(p<0,05)$, а комбінація лізиноприлу з амлодипіном застосовувалась у пацієнтів, у яких не вдавалося досягти адекватного контролю АТ після попереднього застосування препаратів інших груп.

Найбільший вплив на частоту серцевих скорочень (ЧСС) як маркер можливих серцево-судинних ускладнень мало поєднання карведилол+гідрохлортіазид (на 27,51 \%), тоді як Мікардис Плюс найменше впливав на зменшення ЧСС протягом доби (7,56 \%). Лізиноприл+амлодипін за ефективністю впливу на ЧСС займав проміжну позицію на $10,11 \%$.

Суттєвої переваги однієї комбінації антигіпертензивних препаратів перед іншою за впливом на добовий профіль АТ відмічено не було, що 
Огляди літератури, оригінальні дослідження, погляд на проблему, ювілеї

вважали позитивним результатом, оскільки це підтвердило високу і зіставну ефективність застосування всіх трьох комбінацій для корекції АТ у такої проблемної групи пацієнтів у умовах амбулаторної медицини.

Важливим вважали встановлення достовірного зменшення загального периферійного судинного опору (ЗПСО) і питомого периферійного судинного опору (ППСО) під впливом усіх досліджуваних антигіпертензивних комбінацій (сумарно відповідно на 12,50 \%, 11,25 \% і 15,92 \%). Це сприяло покращенню умов для перфузії крові в ішемізованих тканинах нижніх кінцівок, а відтак покращенню периферійної гемодинаміки. При порівнянні позитивного впливу на ЗПСО та ППСО найефективнішою виявилася медикаментозна комбінація лізиноприлу і амлодипіну.

Для оцінки ремоделювання судин під впливом комбінації антигіпертензивних препаратів визначали товщину комплексу інтима-медіа (TIM) та ії динаміку, що має важливе значення для оцінки запобігання серцево-судинним ускладненням під впливом лікування. Встановили, що через 6 місяців лікування вказаними комбінаціями препаратів ТІМ зменшувалась відповідно на 14,63 \%, 15,19 \% і 17,15 \% при застосуванні комплексів карведилол+гідрохлортіазид, телмісартан+гідрохлортіазид і лізиноприл+амлодипін.

Висновки. Порівняння впливу комбінацій антигіпертензивних препаратів карведилол+гідрохлортіазид, телмісартан+гідрохлортіазид і лізиноприл+амлодипін дозволило зробити висновки: 1. Зазначені комбінації антигіпертензивних препаратів забезпечують стабільний і рівномірний гіпотензивний ефект протягом доби і мають коригуючий вплив на добовий профіль артеріаль- ного тиску, достовірно знижуючи середньодобовий, середньоденний і середньонічний систолічний і діастолічний артеріальний тиск, а також частоту серцевих скорочень.

2. Зазначені комбінації антигіпертензивних препаратів у хворих на АГ, що поєднується із атеросклеротичними ураженнями магістральних артерій нижніх кінцівок, при гіперкінетичному або еукінетичному типі центральної гемодинаміки із превалюванням симпатичної нервової системи позитивно впливають на основні показники центральної та периферійної гемодинаміки.

3. Антигіпертензивна комбінація препаратів лізиноприл+амлодипін $\epsilon$ найбільш вдалою для лікування хворих на артеріальну гіпертензію у поєднанні з атеросклеротичними ураженнями магістральних артерій нижніх кінцівок за впливом на досягнення цільового рівня артеріального тиску протягом 6 місяців, за сумарним впливом на параметри загального і питомого периферійного судинного опору і рівень ремоделювання судин (за товщиною комплексу інтима-медіа).

4. Позитивний вплив досліджених комбінацій антигіпертензивних препаратів на периферійну гемодинаміку може дати можливість зменшити дозу судинорозширювальних препаратів, що застосовуються для лікування хронічної артеріальної ішемії нижніх кінцівок.

у перспективі подальших досліджень вважаємо за доцільне вивчення можливості зменшення дози судинорозширювальних препаратів, що застосовуються для лікування хронічної артеріальної ішемії нижніх кінцівок при ії̈ коморбідності з артеріальною гіпертензією за рахунок застосування вищезазначених антигіпертензивних комбінацій препаратів першої лінії.

\section{ЛІТЕРАТУРА}

1. Венгер І. К. Непрямі реваскуляризуючі операції в лікуванні критичної ішемії нижніх кінцівок / І. К. Венгер, П. В. Гощинський, І. О. Крицький // Шпитальна хірургія. 2005. - № 2. - С. 32-36.

2. Кондратюк В. Є. Застосування комбінації лізиноприлу та гідрохлортіазиду у фіксованих дозах у хворих старшого віку з артеріальною гіпертензією/В. Є. Кондратюк // Кровообіг та гемостаз. - 2016. - № 4. - С. 29-34.

3. Конради А. О. Центральная, периферическая и почечная гемодинамика у больных гипертонической болезнью на фоне длительной монотерапии эналаприлом и комбинации с гидрохлортиазидом (по данным ис- следования RU-003) / А. О. Конради, Р. Х. Афаунов, O. В. Мамонтов, А.А. Пушкарев // Артериальная гипертензия. - 2014. - Т. 10. - № 1. - С. 19-22.

4. http://www.onlinejacc.org/content/accj/early/2017/ 11/04/j.jacc.2017.11.005.full.pdf - Нові рекомендації з лікування артеріальної гіпертензії.

5. Lindgren P. Економічна оцінка дослідження ASCOT-BPLA: схема антигіпертензивного лікування на основі амлодипіну має ліпше співвідношення вартість/ ефективність порівняно зі схемою на основі атенололу / P. Lindgren, M. Buxton, T. Kahan // Медицина світу. 2007. - T. XXIII. - 6. - C. 376-381. 
Огляди літератури, оригінальні дослідження, погляд на проблему, ювілеї REFERENCES

1. Wenher, I.K., Hoshchynskyi, P.V., \& Krytskyi, I.O. (2005). Nepriami revaskuliaryzuiuchi operatsii v likuvanni krytychnoi ishemii nyzhnikh kintsivok [Indirect revascularization operations in the treatment of critical ischemia of the lower extremities]. Shpytalna khirurhiia - Hospital Surgery, 2, 32-36 [in Ukrainian].

2. Kondratiuk, V.E. (2016). Zastosuvannia kombinatsii lizynoprylu ta hidrokhlortiazydu u fiksovanykh dozakh u khvorykh starshoho viku z arterialnoiu hipertenziieiu [Application of the combination of lisinopril and hydrochlorothiazide in fixed doses in elderly patients with arterial hypertension]. Krovoobih ta hemostaz - Blood Circulation and Hemostasis, 4, 29-34 [in Ukrainian].

3. Konrady, A.O., Afaunov, R.Kh., Mamontov, O.V., \& Pushkarev, A.A. (2014). Tsentralnaya, peryfericheskaya i pochechnaya gemodinamika u bolnykh gipertonicheskoy boleznyu na fone dlitelnoy monoterapii enalaprylom i kombinatsii s gidrokhlortiazidom (po dannym issledovaniya

RU-003) [Central, peripheral and renal hemodynamics in patients with hypertension due to long-term monotherapy with enalapril and combination with hydrochlorothiazide (according to research data RU-003)]. Arterialnaya gipertenziya - Arterial Hypertension, 10, 1, 19-22 [in Russian].

4. Novi rekomendatsii z likuvannia arterialnoi hipertenzii [New Guidelines for Treating Arterial Hypertension]. Retrieved from: http://www.onlinejacc.org/content/accj/ early/2017/11/04/j.jacc.2017.11.005.full.pdf [in Ukrainian].

5. Lindhren, P., Buxton, M., \& Kahan, T. (2007). Ekonomichna otsinka doslidzhennia ASCOT-BPLA: skhema antyhipertenzyvnoho likuvannyi na osnovi amlodypinu maie lipshe spivvidnoshennia vartist/efektyvnist porivniano zi skhemoiu na osnovi atenololu [Economic evaluation of the ASCOT-BPLA study: An amlodipine-based antihypertensive treatment scheme has better value efficiency compared to atenolol]. Medytsyna svitu - World Medicine, XXIII, 6, 376-381 [in Ukrainian].

\title{
РАЦИОНАЛЬНЫЙ ВЫБОР КОМБИНАЦИИ АНТИГИПЕРТЕНЗИВНЫХ ПРЕПАРАТОВ ПРИ АРТЕРИАЛЬНОЙ ГИПЕРТЕНЗИИ С ОБЛИТЕРИРУЮЩИМ АТЕРОСКЛЕРОЗОМ НИЖНИХ КОНЕЧНОСТЕЙ В АМБУЛАТОРНОЙ ПРАКТИКЕ
}

\author{
๑Л. С. Бабинец, В. В. Билочицька, Ю. Я. Коцаба \\ ГВУз «Тернопольский государственный медицинский университет имени И. Я. Горбачевского \\ МОЗ Украины»
}

РЕЗЮМЕ. Проведено исследование влияния комбинации антигипертензивных препаратов на основные показатели центральной и периферической гемодинамики у 96 больных артериальной гипертензией с атеросклеротическим поражением периферических артерий нижних конечностей.

Цель исследования - изучить влияние антигипертензивных препаратов различных групп первой линии на центральную, периферическую и внутрисердечную гемодинамику с целью выбора оптимальной комбинации этих препаратов для лечения больных артериальной гипертензией с поражением периферических артерий нижних конечностей на этапе первичной медицинской помощи.

Выводы. Сравнительная оценка влияния комбинаций карведилол+гидрохлортиазид, телмисартан+гидрохлортиазид и лизиноприл+амлодипин констатировала: 1) указанные комбинации антигипертензивных препаратов обеспечивают стабильный и равномерный гипотензивный эффект в течение суток и имеют корректирующее воздействие на суточный профиль артериального давления, достоверно снижая среднесуточное, среднедневное и средненочное систолическое и диастолическое артериальное давление, а также частоту сердечных сокращений; 2) указанные комбинации антигипертензивных препаратов у больных АГ, сочетающейся с атеросклеротическими поражениями магистральных артерий нижних конечностей, при гиперкинетическом или эукинетическим типе центральной гемодинамики с преобладанием симпатической нервной системы положительно влияют на основные показатели центральной и периферической гемодинамики; 3) антигипертензивную комбинацию препаратов лизиноприл + амлодипин следует считать наиболее удачной для лечения больных артериальной гипертензией в сочетании с атеросклеротическими поражениями магистральных артерий нижних конечностей по влиянию на достижение целевого уровня артериального давления в течение 6 месяцев, по суммарным воздействиям на параметры общего и удельного периферического сосудистого сопротивления и уровень ремоделирования сосудов (по толщине комплекса интима-медиа); 4) положительное влияние исследованных комбинаций антигипертензивныхпрепаратов на периферическую гемодинамику может дать возможность уменьшить дозу сосудорасширяющих препаратов, применяемых для лечения хронической артериальной ишемии нижних конечностей.

КЛючЕВЫЕ СЛОВА: артериальная гипертензия; антигипертензивная терапия; облитерирующий атеросклероз; карведилол; телмисартан; амлодипин. 


\section{Огляди літератури, оригінальні дослідження, погляд на проблему, ювілеї \\ RATIONAL SELECTION OF COMBINATION OF ANTIHYPERTENSIVE DRUGS IN ARTERIAL HYPERTENSION WITH CORROSIVE ATHEROSCLEROSIS OF LOWER LIMBS IN AMBULATORY PRACTICE}

\section{Horbachevsky Ternopil State Medical University}

SUMMARY. Introduction. The study of the effect of a combination of antihypertensive drugs on the main indicators of central and peripheral hemodynamics of 96 patients with arterial hypertension with atherosclerotic lesions of the peripheral arteries of the lower extremities has been conducted.

The aim of the study - to learn the effect of antihypertensive drugs of different groups of the first line on central, peripheral and intracardiac hemodynamics in order to select the optimal combination of these drugs for the treatment of patients with arterial hypertension with peripheral arterial lesions in the lower limbs at the primary care stage.

Conclusions. The comparative assessment of the effects of combinations of carvedilol+hydrochlorothiazide, telmisartan+hydrochlorothiazide and lisinopril+amlodipine stated: 1) These combinations of antihypertensive drugs provide a stable and uniform antihypertensive effect during the day and have a corrective effect on the daily blood pressure profile, significantly lowering the average daily, midday and middle systolic and diastolic blood pressure, as well as heart rate; 2 ) the indicated combinations of antihypertensive drugs in patients with hypertension, which is combined with atherosclerotic lesions of the major arteries of the lower extremities, with hyperkinetic or eukinetic type of central hemodynamics with the prevalence of the sympathetic nervous system positively affects the main indicators of central and peripheral hemodynamics; 3 ) the antihypertensive combination of lisinopril + amlodipine should be considered the most successful treatment for patients with arterial hypertension in combination with atherosclerotic lesions of the major arteries of the lower extremities for the effect on achievement of the target blood pressure level for 6 months, for the total effect on parameters of general and specific peripheral vascular resistance and the level of vascular remodeling (according to the thickness of the intima-media complex); 4) the positive effect of the studied combinations of antihypertensive drugs on peripheral hemodynamics may give the opportunity to reduce the dose of vasodilators used for the treatment of chronic arterial ischemia of the lower extremities.

KEY WORDS: arterial hypertension; antihypertensive therapy; obliterating atherosclerosis; carvedilol; telmisartan; amlodipine.

Отримано 11.11.2018 